\title{
Correcting the record: Australian prosecutions for manslaughter in the medical context
}

\section{David J Carter}

The failure to prosecute Dr Jayant Patel successfully for any of the deaths associated with his time as Director of Surgery at Bundaberg Base Hospital was received in some quarters as an abject failure of the criminal law to deal adequately with significant wrongdoing. The case itself, the multiple public inquiries and the significant expense to pursue, extradite and prosecute Patel, resulting finally in a finding of guilt on a number of minor fraud charges, seems to compound this sense of failure. This article argues otherwise. When placed within the far longer and forgotten history of the prosecution of manslaughter by criminal negligence in the Australian jurisdiction, this story of prosecutorial failure becomes instead wholly consistent with the case law over time. No adequate account of the history of prosecution in the Australian jurisdiction exists for this area of law. To present Patel in context, the article draws upon archival research to provide a significantly extended account of the history of prosecution for manslaughter in the health care context. The extension of the case law is significant, from four known prosecutions, case histories of another 33 inadequately acknowledged prosecutions are presented.

\section{ContextuAlising PATEL}

The prosecution of manslaughter by criminal negligence or its cognate offences is a complex undertaking. Similarly, such an offence represents one of the most difficult points of interface between the law and health care. The legitimacy of any such intervention is regarded widely as unhelpful to the ongoing work of sustainably reducing preventable adverse events, forms of iatrogenic harm which arise from the actual treatment of a disease or injury rather than the underlying condition itself. ${ }^{1}$ Despite this broadly accepted perspective in the professional literature, criminal offences of manslaughter by criminal negligence exist and are pursued. The complex case of Jayant Patel is one such instance. ${ }^{2}$ Here the aim is to render the Patel case in a more comprehensive prosecutorial context. To do so, a revised and expanded history of prosecution in the Australian jurisdiction is presented, which expands the known prosecutions of manslaughter in the health care context from four doctors to include an additional 33. To present Patel's case in this way does not aim to efface the otherwise

* BA Communications (Social Inquiry), LLB (Hon I), LLM (Research) (UNSW), GradDipTheol (MCD), PhD Candidate (UTS), Quentin Bryce Law Doctoral Scholar and Teaching Fellow, Faculty of Law, University of Technology, Sydney. The research for this article was undertaken as part of a PhD at the University of Technology, Sydney. The author thanks Professor Katherine Biber, Associate Professor Angus Corbett and Associate Professor Penny Crofts for their generous feedback and encouragement at every stage of this research.

Correspondence to: david.carter@uts.edu.au.

${ }^{1}$ See, for example, Quick O, "Medical Manslaughter: The Rise (and Replacement) of a Contested Crime" in Erin CA and Ost S (eds), The Criminal Justice System and Health Care (Oxford University Press, 2007); Quick O, "Outing Medical Errors: Questions of Trust and Responsibility" (2006) 14 Med Law Rev 22; Quick O, "Prosecuting 'Gross' Medical Negligence: Manslaughter, Discretion, and the Crown Prosecution Service" (2006) 33 J Law Soc 421; Merry A and Smith AM, Errors, Medicine and the Law (Cambridge University Press, 2001); Merry AF, "How Does the Law Recognize and Deal with Medical Errors?" (2009) 102 JRSM 265; Dekker S, Just Culture: Balancing Safety and Accountability (Ashgate Publishing Co, 2007).

${ }^{2}$ The series of cases related to Patel are explored below. For an indepth introduction and overview of the complex background to the cases, see the introduction in Dunbar J, Reddy P and May S, Deadly Healthcare (Australian Academic Press, 2011); Thomas H, Sick to Death: A Manipulative Surgeon and a Health System in Crisis - A Disaster Waiting to Happen (Allen \& Unwin, 2007). The High Court provides an overview of the case at first instance and subsequent appeal in Patel v The Queen (2012) 247 CLR 531. 
important contexts within which his case can be rendered. ${ }^{3}$ Rather, the contextualisation aims to place the prosecutorial history of Patel into a more accurate historical light.

\section{SEEKING OUt PROSECUtions IN THE AUSTRALIAN JURISDICTION}

Patel faced prosecution in a series of cases following initial whistleblowing by Bundaberg Base Hospital staff, an aborted and one completed public inquiry and extradition proceedings from the United States. The completed inquiry, the Davies Commission, found amongst other things that as a result of negligence on the part of Patel, 13 patients died, patients he had operated on whilst Director of Surgery at Bundaberg Base Hospital in rural Queensland. Both reports recommended that Patel be investigated for either murder or manslaughter and, as is the practice of the media in cases of this nature, Patel was labelled with the epithet "Dr Death". He was found guilty at trial for the death of three patients and the grievous bodily harm of a fourth patient. ${ }^{4}$ Proceeding to appeal, the Queensland Court of Appeal upheld the finding of guilt, while the High Court subsequently quashed all counts due to a miscarriage of justice. ${ }^{5}$ Re-tried in separate trials, each for an individual patient under his care, Patel was found not guilty but pleaded guilty in relation to fraud in obtaining his registration. He has since launched proceedings against his solicitor and one barrister for damages arising from the conduct of his defence. ${ }^{6}$ The decision by the Director of Public Prosecutions to cease pursuing Patel in late 2013 was described as a "major disappointment"7 to patients and their families. It was described in similar terms by the Premier of Queensland at the time of his arrest, Peter Beattie, ${ }^{8}$ alongside former Attorney-General Jarrod Bleijie. ${ }^{9}$

To make sense of this prosecutorial outcome seems a difficult undertaking. In the Australian context, the extant literature on criminal prosecutions for medical or health care related manslaughter is quite small. ${ }^{10}$ What has been produced focuses on working to locate the very few cases known to the literature within the doctrinal structure of manslaughter by criminal negligence and negligencerelated manslaughter offences with some treatment of the broader policy questions prosecution raises. The 1843 Tasmanian case of Dr Valentine ${ }^{11}$ was identified as the only successful prosecution for medical manslaughter, with Patel's conviction in due course being overturned. ${ }^{12}$ Dobinson rightly highlighted the paucity of available literature for both convictions and prosecutions more generally, noting that "it is very difficult to be certain but there is a strong likelihood that only three doctors and

\footnotetext{
${ }^{3}$ The various contexts include health care quality and safety, the political economy of rural health care, and the challenges of overseas trained medical practitioners, as well as clinical governance and systemic failures within Bundaberg Base Hospital. Doctrinal contexts include the ongoing discomfort many feel with forms of criminal liability based on objective standards such as criminal negligence.

${ }^{4} R v$ Patel [2010] QSC 233.

${ }^{5}$ Patel v The Queen (2012) 247 CLR 531.

${ }^{6}$ Dibben K, "Former Bundaberg Hospital Surgeon Jayant Patel Sues His Defence Team for \$884,000", The Courier-Mail (Brisbane) (14 February 2014), http://www.couriermail.com.au/news/queensland/former-bundaberg-hospital-surgeon-jayantpatel- sues-his-defence-team-for-884000/story-fnihsrf2-1226826574144.

${ }^{7}$ Australian Broadcasting Corporation, "Dr Jayant Patel Case Leaves Legacy of Change in Health", AM (16 November 2013) (comments by Professor Andrew Wilson, former Deputy Director of Queensland Health), http://www.abc.net.au/am/ content/2013/s3892392.htm

${ }^{8}$ Elks S, "Jayant Patel Guilty of Fraud as Crown Gives up Chase", The Australian (16 November 2012), http:// www.theaustralian.com.au/news/nation/patel-guilty-of-fraud-as-crown-gives-up-chase/story-e6frg6nf-1226761416481.

${ }^{9}$ Elks, n 8.

${ }^{10}$ Dobinson I, "Medical Manslaughter" (2009) 28 U Qld LJ 101; Dobinson I, "Doctors Who Kill or Harm Their Patients: The Australian Experience" in Griffiths D and Sanders A (eds), Bioethics, Medicine and the Criminal Law: Medicine, Crime and Society (Cambridge University Press, 2013); Tuckett N, "Balancing Public Health and Practitioner Accountability in Cases of Medical Manslaughter: Reconsidering the Tests for Criminal Negligence-Related Offences in Australia after R v Patel” (2011) 19 J Law Med 377

${ }^{11} R v$ Valentine [1842] TASSupC 4 .

${ }^{12}$ Patel $v$ The Queen (2012) 247 CLR 531.
} 
[one] dentist have ever been charged since Dr Valentine [in 1843]". ${ }^{13}$ Such a limited literature is unable to provide significant contextualisation for a case like Patel, except to say that his prosecution represents one of five health practitioners (including one dentist) known to have been charged. Context is available from other common law jurisdictions. Oliver Quick analysed the United Kingdom experience reporting that of prima facie cases of medical manslaughter reported in the United Kingdom media between 1976 and 2005 (64 in total), 14 health care practitioners (including alternative medicine, nurses and others) were convicted of some form of medical manslaughter thus creating a conviction rate of 39\%. Robin Ferner and Sarah McDowell provided a more complete review, drawing in cases as early as $1795,{ }^{14}$ which was received with some reservation by the Crown Prosecution Service. ${ }^{15}$ Quick's findings showed that conviction rates are lower than that for manslaughter generally but, in contrast to the literature in Australia, he showed, with Ferner and McDowell confirming and extending, that a significant cohort of cases exist in the United Kingdom in the period where none is said by the literature to have been successfully prosecuted in the Australian jurisdiction. ${ }^{16}$

To establish the incidence of medical manslaughter prosecutions in the Australian jurisdiction, the method used by Quick, which relied on media accounts of prosecutions, is replicated here. ${ }^{17}$ There are, however, complications with applying this method, as acknowledged by Quick and Ferner and McDowell, in particular with the use of media publications to establish the aetiology of the prima facie manslaughter, ${ }^{18}$ and, to echo Dobinson, it remains very difficult to be certain about the total number of cases. Stephen O'Doherty of the Crown Prosecution Service similarly has cited media reporting as "notoriously unreliable" for the communication of evidence and the true nature of a case. $^{19}$

The results reported here extend the Australian literature significantly. From a base of four prosecutions of doctors and one dentist known to the literature, a further 33 relevant prosecutions not reported in the literature to date were uncovered. ${ }^{20}$ They provide earlier precedent with the 1839 case surrounding Dr Durie of Tasmania, ${ }^{21}$ and more contemporary prosecutions including the case of

${ }^{13}$ Dobinson, "Medical Manslaughter", n 10 at 102.

${ }^{14}$ Ferner RE and McDowell SE, "Doctors Charged with Manslaughter in the Course of Medical Practice, 1795-2005: A Literature Review” (2006) 99 JRSM 309.

${ }^{15}$ Ferner and McDowell, n 14. For the response from the Crown Prosecution Service, see Ferner RE and McDowell SE, "Doctors and Manslaughter - Response from the Crown Prosecution Service Authors' Reply" (2006) 99 JRSM 544. A similar method to that employed by Ferner and McDowell is adopted here, however, cases of unregistered doctors and other similar classes are not specifically excluded. Instead, the professional status of those prosecuted is noted. Here the aim is to provide a broader picture of the engagement between health care and the criminal law.

${ }^{16}$ Dobinson wrote that charges against Dr Bruce Ward were laid in 2007, with these subsequently dropped whilst in New South Wales, Dr Gerrit Reimers was acquitted in 2001: Dobinson, "Doctors Who Kill or Harm Their Patients", n 10 , p 256.

${ }^{17}$ A search was conducted using both the National Library of Australia's Trove service which indexes, catalogues and stores digitised images of Australian newspapers and magazines from the 18th century to the late 20th century, and more recent holdings of media reports held by Factiva. Following the method adopted by Quick, a keyword search on the material was made utilising key words: "manslaughter, coroner, medical, doctor, hospital, and error". The results were narrowed to cases of prima facie medical manslaughter. Recently, the Australasian Legal Information Institute (AustLii) has begun to recover colonial cases from similar sources for the Australasian Colonial Legal History Library.

${ }^{18}$ Ferner and McDowell, "Doctors and Manslaughter - Response", n 15 at 544.

${ }^{19}$ Ferner and McDowell, "Doctors and Manslaughter - Response", n 15 at 544.

${ }^{20}$ This excludes the vast majority of cases which were related to the provision of termination services by medical practitioners, nurses, midwives and unregistered or other non-professionals (see below for discussion of these cases).

${ }^{21}$ Various factors conspire to render access to these cases difficult. All are unreported and most exist now only in the form of newspaper reports of the time. For this reason, where a citation can be given to helpfully locate case materials, it is given in the usual format. For the cases that are discoverable only through media reports, reference to reports and cases are notated by the year of prosecution in brackets following the surname of the defendant. See "Coroner's Inquest", Launceston Advertiser (Launceston) (18 July 1839) p 3; "Inquests", Cornwell Chronicle (Launceston) (20 July 1839) p 1; "Wednesday, Oct 9", Launceston Advertiser (Launceston) (10 October 1839) p 3; "Wednesday, October 9", Cornwell Chronicle (Launceston) (12 October 1839) p 3. 
Dr Arthur Garry Gow of New South Wales in $2004 .^{22}$ Twenty-six of these cases resulted in a trial, with four findings of guilt, nine acquittals and the remainder being either aborted due to withdrawal of charges or the result remaining unknown. Cases include early coronial inquests where the practice of finding both cause of death and prima facie finding of guilt for manslaughter were followed by committal for trial. ${ }^{23}$ The research presented here extends historical precedent with the case of Dr Durie (1839) now being the earliest case of prosecution known to have occurred in Australia. ${ }^{24}$ Dr Degner (1861) replaces Dr Gerrit Reimer (acquitted, 2001) as the earliest known charge and trial in New South Wales legal history. Similarly, in Queensland, where the case of Dr Bruce Ward was understood to be the first trial for manslaughter in that jurisdiction, ${ }^{25}$ it is now clear that Dr Margaret Joy Pearce (2000) was the first doctor to be tried. She is also the first to be found guilty of manslaughter in that jurisdiction. ${ }^{26}$ Most significant, however, is the extension beyond only one acknowledged convictions for manslaughter in Australia with four additional convictions, bringing the known total to five successful convictions. ${ }^{27}$ This new cohort allows a rendering of Patel as being more consistent with the experience of health care related prosecutions rather than an anomalous failure to secure conviction.

\section{MANSLAUGHTER PROSECUTIONS}

The expanded cohort of cases is presented thematically. The themes used are an attempt to draw out something of what unites the history of medical manslaughter in Australia and some of the central failures found in the treatment of patients both by Patel and in quality and safety science analysis of preventable adverse events more generally. Both doctrine and the operation of investigative and judicial processes have evolved significantly over time. There was and still remains significant and important differences in doctrine and offence structure between jurisdictions. For this reason, some cases presented here might be understood in some jurisdictions to represent negligence-related manslaughter offences rather than what could be properly described as manslaughter by criminal negligence. ${ }^{28}$ Care has been taken to not overstate the similarity and cohesion amongst the cases health care regulation and the conduct of health care itself has changed dramatically over time however, there remains a pronounced consistency to these cases. The consistency is most obvious in the propensity to fail in securing a conviction and to cluster around a set of persistent characteristics. This includes the legal characteristics of the cases, the type of adverse event, error or behaviour concerned, the role of the coroner, the characteristics of victims and defendants as well as a note on the issue of recidivism and repeat offending. To maintain a sense of the original media report from which most cases are drawn, the reports are paraphrased and summarised using the original language employed by the writer rather than attempting to update or reinterpret dated or unclear reporting of the event. $^{29}$ This account begins by drawing out some of the legal characteristics of these cases, notably the aforementioned failure to convict both historically and in relation to Patel.

${ }^{22}$ Health Care Complaints Commission v Gow [2008] NSWMT No 40011; "Doctor Given Suspended Sentence over Death of Patient", AAP News (27 October 2006).

${ }^{23}$ This is commensurate with the study by Quick which is the foundation of this article's method for seeking out prima facie cases of manslaughter by criminal negligence. See Quick, "Prosecuting 'Gross' Medical Negligence", n 1 at 426.

${ }^{24}$ Replacing the prosecution of Dr Valentine as the earliest known case: $R v$ Valentine [1842] TASSupC 4.

${ }^{25}$ Dobinson, "Doctors Who Kill or Harm Their Patients", n 10, p 257.

${ }^{26}$ Although this fact was not unknown to the Supreme Court of Queensland who considered Dr Pearce's case in relation to the sentence of Dr Patel: $R v$ Pearce (unreported, QSC, Indictment No 96 of 2000, 15 November 2000), cited in $R v$ Patel; Ex parte Attorney-General (Qld) [2011] QCA 81 at 204.

${ }^{27}$ The only known conviction being Dr Valentine (1842) now joined by Dr Hornbrook (1864), Charles Zimmler (1871), Dr Margaret Pearce (2000) and Dr Arthur Garry Gow (2004).

${ }^{28}$ See for instance the treatment of Queensland "criminal negligence-related offences" in Tuckett, n 10.

${ }^{29}$ This approach means that descriptions of medical procedures, treatment and diagnoses in this article may at times seem at odds with contemporary usage or knowledge and that expressions used by the reporters, coroners or courts find their way into the descriptions of cases discussed here. As the cases extend over such a significant period of time, the practice of medicine, its language and techniques shift significantly. In recounting these cases, the aim is to maintain, where possible, the language in which the cases were described, including medical terminology of the time. 


\section{“LEGAL” CHARACTERISTICS AND THEMES}

Manslaughter by criminal negligence is difficult to prosecute ${ }^{30}$ and the cases presented here strongly support that contention. In the matter of Patel, dissatisfaction with the management of arguments presented the Crown at trial, led to a notably terse judgment by the High Court as it recounted the miscarriage of justice which the prosecutorial strategy created. ${ }^{31}$ The court decided to quash Patel's convictions. $^{32}$ This was a high-profile failure of the legal system to engage adequately with gross and systemic wrongdoing on its own terms; whilst there was difficult evidence to integrate into a prosecution, fundamentally the case at first instance was a failure of prosecutorial strategy and management. This is of course not isolated to Queensland or Patel. ${ }^{33}$ The similarly failed attempts to respond to the Chelmsford disaster by the criminal law are evidence of the complexity of this area of legal practice and law's use in health care contexts. ${ }^{34}$ So too is this mirrored in cases far older than these examples as is shown here below. ${ }^{35}$

The trial of Dr Henry Marshall Fenwick (1895) is perhaps the most direct in its connection with the prosecutorial process of Patel. Mirrored in the High Court's portrayal of the conduct of the prosecution of Patel's case are the words of A'Bekett J in Fenwick's case. A'Bekett J expressed "astonishment at the miserable way in which the case had been presented for the Crown", 36 with argument being reported as both "weak [and] disorganised". ${ }^{37}$ Fenwick had treated Mary Beekman for review of a post-operative bleed. It was reported that she had been treated by another practitioner for miscarriage. ${ }^{38}$ In the course of providing aftercare, Fenwick undertook to remove biological matter and in the process removed pieces of flesh which were reported to have been a part of her intestines. The patient was not sedated. ${ }^{39}$ Fenwick was reported to have made a "hasty exit" ${ }^{40}$ from the home of

${ }^{30}$ Dobinson, "Medical Manslaughter", n 10.

${ }^{31}$ Patel v The Queen (2012) 247 CLR 531.

${ }^{32}$ Patel was to be subject to fresh trials on separate counts of manslaughter. Having failed in the first two such trials to secure a conviction, Patel pled guilty to four counts of fraud and returned to the United States: $R v$ Patel (unreported, QDC, Indictment No 1701 of 2013, 21 November 2013).

${ }^{33}$ The question as to whether or how the criminal law might be a suitable place for the engagement with such actions, or in fact if they represent "wrongdoing", is, in this context, beside the point.

${ }^{34}$ Chelmsford Hospital was a small cottage hospital in the Northern suburbs of Sydney where, during the 1960s and 1970s, four doctors administered "Deep Sleep Therapy", resulting in the death of 26 patients and the suicide of a further 22 . A Royal Commission was called and various disciplinary charges were laid. Criminal charges against Dr Bailey in 1985, ended with his suicide shortly afterwards. Disciplinary proceedings against Drs Herron and Gill ceased with the High Court upholding a permanent stay of proceedings due to protracted delays brought about by virtue of extended legal disputes launched by the defendants. So too were criminal charges similarly dropped, with the Director of Public Prosections choosing not to proceed with manslaughter charges against Drs Herron and Gill after the Supreme Court issued a stay of criminal proceedings citing concern that they would not be able to receive a fair trial.

35 The cases of Dr Oakley Robert Small (1999), Dr Bruce Ward (2002), Drs Harry Bailey, John Tennant Herron and John Edward Gill (1985), Dr Atlee Clarke (1896), Dr Spark and "Professor" Davies (1897), and Dr Berthold Hiller (1941), amongst others, all exhibit the difficulties of prosecuting cases of this nature, including the unexpected nature of decisions and behaviour of juries. Each of these cases is detailed further below.

36 “Alleged Manslaughter. A Carlton Doctor Charged. Verdict of Not Guilty", The Argus (Melbourne, Victoria) (29 March 1895) p 7.

${ }^{37}$ So to was the High Court to describe the conduct of Patel's case in similar terms with Heydon J in Patel v The Queen (2012) 247 CLR 531 recounting in relation to the prosecution's provision of particulars that: "On the fifth day of the trial ... 'draft particulars' of the case concerning [one alleged victim] ... [were] handed to the trial judge. The transcript then attributes to his Honour the expression: 'Mmm.' Prosecution counsel then said: 'Your Honour, it troubles me with the - your Honour just expressed some concern, I thought.' The trial judge agreed" (at [175]). Moreover, Heydon J continues: "On the tenth and eleventh days of the trial, the trial judge ... had pressed for final particulars [in relation to another alleged victim] ... [and] on the twelfth day, Thursday 8 April 2010, the trial judge read those particulars. His Honour said: 'Oh, dear.'” (at [181]).

38 “Alleged Manslaughter. A Carlton Doctor Charged. Verdict of Not Guilty”, n 36.

39 "Alleged Manslaughter. A Carlton Doctor Charged. Verdict of Not Guilty", n 36. Evidence was given that the post-mortem revealed that the woman was killed by "having her intestines dragged out of her by the accused".

40 “Alleged Manslaughter. A Carlton Doctor Charged. Verdict of Not Guilty”, n 36. 
the victim, noting to her waiting husband as he passed by that she was going to die. The prosecution was criticised for calling an assistant junior surgeon rather than the senior surgeons who had performed the first operation. ${ }^{41}$ The judge strongly criticised the Crown's case in so far as it had taken until the very last moment for the prosecution to present a definite idea of the cause of death. As will be explored below, the prosecution in Patel's first trial had taken an extended period of time for final particulars of the matter to be presented, much to the annoyance of the judge. The similarities between this case and that of Patel both in terms of alleged lack of acceptable surgical skill, ${ }^{42}$ as well as criticism of the prosecution's inability to identify causation clearly and accurately or to structure their case clearly and accurately are striking.

Difficulties with the conduct of coronial inquests also feature in some of the early Australian inquests, ${ }^{43}$ with these developing into difficulties for prosecution later. Dr Heeley (1876) was the subject of one such inquest before Coroner Armstrong in relation to the death of Eliza Jane Davis at Three-Mile, near Young in rural New South Wales. ${ }^{44}$ At the inquest, it was clear that the victim had been confined for birth of a female child. She had been reported to have been "very well" 45 until some hours into her labour when she began to vomit violently. The attending midwife applied a mustard plaster and sent for Heeley. ${ }^{46}$ Heeley dispensed medicine which included carbolic acid which caused the deceased to experience what was described as a fainting spell and convulsions. This was reported to Heeley, and in the meantime the patient died. Heeley is reported to have said that it "was useless going to see a dying woman". ${ }^{47}$ Nevertheless, the messenger saddled Heeley's horse and they set off together. On the journey, news reached them that she had in fact died. Heeley then said: "People don't die off like this. They must have given her something to have killed her." 48 Cuthbert Powell, the chemist's assistant to Heeley, gave evidence at the inquest that the medicine dispensed should not have caused the death of the deceased. ${ }^{49}$ Heeley at this point submitted a protest to the inquest, stating that the inquest was illegal:

First, because it had been commenced on a Sunday, which was not a legal day for holding it. Secondly, because the post-mortem examination had been made by a medical practitioner who was not on friendly terms with him, and in his absence. And thirdly, because the Coroner was himself unfriendly to him, and had already expressed an opinion that the death of the deceased, was caused by his, Dr Heeley's, negligence. ${ }^{50}$

The doctor who was not on friendly terms with Heeley was a Dr Temple. Temple, a government medical officer, had concluded that he could only account for the death by supposing that the carbolic acid was too concentrated, causing irritation of the epiglottis, causing convulsive closing of the

\footnotetext{
41 “Alleged Manslaughter. A Carlton Doctor Charged. Verdict of Not Guilty”, n 36.

${ }^{42}$ Upon which the prosecution based its case in the original trial, subsequently altering its approach midway through the proceedings, a shift which caused in large part the miscarriage of justice found to have occurred by the High Court.

${ }^{43}$ The nature of coronial inquests and their relationship to criminal prosecution were at this time significantly different to today. Coroners made findings of prima facie guilt for criminal offences and empanelled a jury as part of their inquest. The role of juries was much reduced in recent coronial reform in New South Wales: see Coroners Act 2009 (NSW). This Act now clearly defines the use of juries as an exception (s 48(1)) and limited to circumstances where the State Coroner directs that a jury be empanelled (s 48(2)) and in circumstances where the State Coroner is to act as the coroner for the inquest (s 48(3)(a)). See also Waller KM, Waller's Coronial Law and Practice in New South Wales (4th ed, LexisNexis Butterworths, 2010).

44 “Young. Tuesday", The Sydney Morning Herald (Sydney) (15 March 1876) p 5.

45 “A Doctor Charged with Manslaughter", Queanbeyan Age (Queanbeyan) (22 March 1876) p 3.

46 “A Doctor Charged with Manslaughter", n 45.

47 “A Doctor Charged with Manslaughter”, n 45.

48 “A Doctor Charged with Manslaughter", n 45.

${ }^{49}$ The mixture was reported to have been 16 minims of hydrocyanic acid, $1 / 2$ drachm of carbolic acid, two drachms of a compound tincture caramonis, made up to eight ounces with water, two tablespoons to be administered every four hours.

50 “A Doctor Charged with Manslaughter", n 45.
} 
windpipe, by which "the patient lost her breath and was suffocated". 51 Temple reported that prussic or carbolic acid which was prescribed to the patient required far more dilution for it to be safe to consume than had been provided by Heeley.

The record is unclear as to the specific issue between the coroner himself and Heeley. Similarly, what relationship the two had maintained prior to the inquest or any other details are lost. In a rural setting with few professionals of any kind and a small population, no doubt a relationship had been established either by reputation or otherwise. What is known is that the coroner did express his belief that the death was caused by the negligence of Heeley and that the coronial jury ought to return a verdict that would cause the case to be sent to another court. ${ }^{52}$

It was reported that the case had created considerable attention in the local community, with the Burrangong Argus writing that the:

manner in which the inquiry was conducted was something unique as far as British ideas of a Court of Justice go, and that never, during many years reporting in Courts of Justice have we experienced such a feeling of shame as we did through the sitting of this Court. ${ }^{53}$

The Burrangong Chronicle is reported to have been "equally severe" 54 in its treatment of the way in which the inquiry was conducted. The jury at the inquest found that the deceased died of "asphyxia, caused by her taking a dose of medicine prescribed by Dr Heeley ... and containing carbolic acid and prussic acid in too concentrated a form". 55 The jury found Heeley "guilty of malpractice and manslaughter, caused through gross negligence". 56 The coroner committed Heeley for trial at the next Circuit Court, Yass, and granted bail. Like the case of Patel, its transfer to a superior court led to the quashing of the charges. It was reported in the Maitland Mercury and Hunter River General Advertiser on 25 March 1876 that Heeley's committal had been "declared illegal".57

\section{Sentencing}

Sentencing emerges as another key theme which unites these cases across time. Sentences, where they were imposed, often were delivered with a profound sense of regret and of mercy. The case of Valentine, which is known to the literature, resulted in a fine of 25 pounds rather than any custodial sentence. ${ }^{58}$ Valentine had prescribed and dispensed a medicine for a patient mixed with laudanum rather than a less noxious substance as was intended. ${ }^{59}$ This case is joined by a series of sentencing decisions which provide some further insight into sentences for this particular cohort of defendants. The 1864 case of Dr Hornbrook is one such case.

Hornbrook, of Goulburn in New South Wales, was found guilty of the manslaughter of an adult patient after having administered 210 drops of sulphuric acid to him, some 13 times the maximum dose. ${ }^{60}$ After serving approximately one month of his two-year sentence, ${ }^{61}$ he was released by virtue of a vice-regal pardon. ${ }^{62}$ This pardon was made after post-sentence lobbying of the trial judge by the

\footnotetext{
51 “A Doctor Charged with Manslaughter", n 45.

52 This direction is not an unusual one in the era.

${ }^{53}$ As cited in "A Doctor Charged with Manslaughter", n 45.

${ }^{54}$ As cited in "A Doctor Charged with Manslaughter", n 45.

55 "A Doctor Charged with Manslaughter", n 45.

56 “A Doctor Charged with Manslaughter", n 45.

57 "Young", Maitland Mercury and Hunter River General Advertiser (Maitland) (25 March 1876) p 9.

${ }^{58} R v$ Valentine [1842] TASSupC 4.

${ }^{59} R v$ Valentine [1842] TASSupC 4

60 "Manslaughter by a Medical Practitioner", The Empire (Sydney) (8 March 1864) p 8.

61 “Goulburn. Wednesday”, The Empire (Sydney) (28 April 1864) p 4.

62 "The Case of Dr Hornbrook", The Empire (Sydney) (2 September 1864) p 4.
} 
local private medical fraternity of Goulburn, ${ }^{63}$ and one letter to the editor by an anonymous "lover of justice". ${ }^{4}$ This group of doctors in private practice had complained that they had not been called as witnesses. Instead, physicians on the government payroll had been called. ${ }^{65}$

Sentencing is of course a matter which turns on the specific details of the case and a variety of other factors which may lead to sentences that seem to be at odds with the basic contours of liability in a particular case. Sentencing practice has also significantly altered between the context of the early colony and more recent times. Comparison across time is therefore a problematic undertaking. That being said, comparison of sentencing data amongst more recent cases, such as that of Dr Margaret Pearce (2000), may provide some insight into the sentencing of these crimes - albeit at the risk of "flattening out" the case and the grounds for differential sentences.

Both Pearce and her contemporary Dr Gow (2006) received sentences which included custodial terms - Gow receiving an 18-month suspended sentence and Pearce a five-year sentence with six months of incarceration. ${ }^{66}$ Pearce had administered 15 milligrams of morphine to a 15 -month-old child, although the correct dosage should have been 1.5 to 3 milligrams. ${ }^{67}$ She had not taken a medical history of the child, nor had she advised of the type of drug being administered or any risks associated with it. ${ }^{68}$ In a submission to re-open her case after sentence, the Crown was reported to have argued that Pearce was facing disciplinary proceedings at the time of the manslaughter for self-administration of pethidine during 1998 and 1999 and that she was not able to keep a range of drugs in her surgery, including morphine. ${ }^{69}$

In New South Wales at the time, 96.2\% of all convictions for manslaughter received a prison sentence with the average aggregate sentence for manslaughter being seven years with an average minimum of 4.5 years. ${ }^{70}$ Gow was able to practise medicine after being found guilty of manslaughter with restrictions on his practice. ${ }^{71}$ Pearce, who had voluntarily de-registered herself in 2000 , after being found guilty of manslaughter, is entitled to practise after having served a period of suspension of two years. ${ }^{72}$ The Queensland Health Practitioners Tribunal noted that the manslaughter finding and inability to practise medicine "had a devastating effect on her life". ${ }^{73}$ The tribunal noted the "public shame and humiliation" 74 associated with the court proceedings she had endured as well as financial suffering which had caused her to "find employment as a taxi driver". ${ }^{75}$ She received a two-year suspension of her registration running from the date of criminal sentence. A new registration was granted in March 2003, whilst still serving a suspended sentence for manslaughter.

\footnotetext{
63 "The Case of Dr Hornbrook", n 62; "To the Editor of the Queanbeyan Age", Queanbeyan Age and General Advertiser (Queanbeyan) (1 September 1864) p 2.

64 "To the Editor of the Herald and Chronicle", Goulburn Herald and Chronicle (Goulburn) (30 April 1864) p 5.

${ }^{65}$ Although unclear as to the central objection, the calling of doctors in the employment of government is again objected to in relation to the case of Dr Heeley (1876).

66 "Doctor Given Suspended Sentence over Death of Patient", n 22.

${ }^{67}$ Medical Board of Queensland v Pearce [2001] QHPT 004 at [3] (O’Brien J, Dr Richards, Dr Doughty, Member Langley).

${ }^{68} R$ v Pearce (unreported, QSC, Indictment No 96 of 2000, 15 November 2000); "She went to the Clinic with a Burnt Hand The Next Day She Was", The Advertiser (Adelaide) (10 July 1999) p 28.

${ }^{69}$ Vale B, "GP Known for Taking Painkillers, Court Told”, The Courier-Mail (Brisbane) (18 November 2000).

${ }^{70}$ Taussig I, "Sentencing Snapshot: Homicide and Related Offences", Bureau Brief Issue Paper No 76 (NSW Bureau of Crime Statistics and Research, February 2012) pp 2-3, http://www.bocsar.nsw.gov.au/agdbasev7wr/bocsar/documents/pdf/bb76.pdf.

${ }^{71}$ Health Care Complaints Commission v Gow [2008] NSWMT No 40011.

${ }^{72}$ Medical Board of Queensland v Pearce [2001] QHPT 004.

${ }^{73}$ Medical Board of Queensland v Pearce [2001] QHPT 004 at [9].

${ }^{74}$ Medical Board of Queensland v Pearce [2001] QHPT 004 at [9].

${ }^{75}$ Medical Board of Queensland v Pearce [2001] QHPT 004 at [9].
} 


\section{Juries and trial process}

Juries were a common feature of early coronial inquests undertaken in this cohort, whether the inquest was made by a coroner or magistrate acting as coroner. In early cases, juries form a prima facie finding, often described as a verdict, in relation to both cause of death and of manslaughter. In the case of Dr Degner (1861), described below, it was reported that the jury itself requested a post-mortem examination to be performed and recalled a witness to revisit evidence which had been provided. In that case, the active jury gave its verdict on the cause of death. They also formed an opinion that Degner was "highly censurable", choosing, however, to "exonerate" Degner from any "wilful attempt to destroy life", 76 offering its severe reprimand instead.

Where they were empanelled, juries at trial were similarly active. In the case of Dr Hillier (1941) of Tasmania, the defendant was the subject of a criminal trial where the prosecution unexpectedly entered a nolle prosequi - no case to answer - thus discharging Hillier. ${ }^{77}$ The previous day, Hillier had taken the stand, but still awaited cross-examination. Upon recommencing, the jury expressed directly to the court that they had unanimously formed an opinion that a conviction could not be recorded against Hillier based on the evidence presented. ${ }^{78}$ As the defendant had yet to be cross-examined, the Crown requested that the jury be discharged and Hillier held in remand until the next sitting of the court, arguing that the jury had formed a conclusion prior to all the evidence being presented. The Solicitor-General, Mr Beedham, who was running the case himself for the Crown, noted that a jury had never expressed an opinion during the course of a trial in his experience. ${ }^{79}$ The Chief Justice refused the application to discharge the jury, noting that the jury had merely expressed an opinion, one which may fluctuate during the case. ${ }^{80}$ The Solicitor-General responded that in his opinion the jury's mind had not simply fluctuated but had called a halt. Feeling it his duty, the Crown entered a nolle prosequi. $^{81}$

Similarly, Dr Featherston (1944) of Maldon in Victoria was charged with manslaughter for the death of Reverend Walter J Ding, 73, a Baptist pastor, caused by peritonitis after an operation at Castlemaine Hospital on 21 June 1944. It was reported that the coroner found that the operation by Featherston had been "performed with negligence of such a degree as to amount to criminal negligence". ${ }^{82}$ The trial was held at Bendigo General Sessions where Featherston entered a plea of not guilty. ${ }^{83}$ The jury did not retire to consider its verdict at all, finding him not guilty. ${ }^{84}$ The judge had given a direction to the jury to the effect that he was satisfied by evidence provided by another surgeon that the accused had made a mistake, and that such an error was one that any skilled "medical man" might also fall into. ${ }^{85}$

Public interest in the practice of medicine was aroused by each of the cases presented here. ${ }^{86}$ Such interest, expressed in the pages of local newspapers, impact upon the prosecution of defendants both in the past and present. Media coverage in Patel's case, spurred action on a case left languishing and provided a parallel extracurial discourse about his actions at Bundaburg. Dr Durie (1839), the

76 "Death by Poisoning", The Sydney Morning Herald (Sydney) (13 July 1861) p 5.

77 “Doctor's trial. Unexpected Ending. Crown Enters Nolle Prosequi”, The West Australian (Perth) (30 August 1941 ) p 6.

78 “Doctor's trial. Unexpected Ending. Crown Enters Nolle Prosequi”, n 77.

79 “Doctor's trial. Unexpected Ending. Crown Enters Nolle Prosequi”, n 77.

80 “Doctor's trial. Unexpected Ending. Crown Enters Nolle Prosequi”, n 77.

81 "Prescriptions by Phone. Letter did not Agree", The Courier-Mail (Brisbane) (28 August 1941) p 7; "Charge Against Doctor", The Argus (Melbourne) (28 August 1941) p 5.

82 "Manslaughter Charge Against Doctor", The Mercury (Hobart) (12 August 1944) p 24.

83 "Doctor Freed; Not Guilty Of Manslaughter", The Barrier Miner (Broken Hill) (14 September 1944) p 3.

84 "Doctor Exonerated Not Guilty of Manslaughter", The Border Watch (Mount Gambier) (14 September 1944) p 1.

85 “Doctor Acquitted Judge's Direction”, The Sydney Morning Herald (Sydney) (14 September 1944) p 4.

${ }^{86}$ Were it not so, no media report would have been generated. There are likely to be other cases unreported by the media concerning prosecutions of manslaughter by criminal negligence. 
earliest known prosecution in Australia, lies at the confluence of public interest in medical practice and service provision and public debate about trial outcome.

Durie was a Tasmanian Assistant Colonial Surgeon stationed in Launceston. He was tried on 9 October 1839, charged with the negligent manslaughter of James Lovett who had died on 12 July earlier that year. Lovett was imprisoned at the tread-mill ${ }^{87}$ in Launceston at the time of his death. ${ }^{88}$ Durie admitted some slight negligence in waiting a day to attend Lovett, believing that the patient was "gammoning" 89 (enacting a hoax in 19th century parlance) coupled by belief that a Dr Secombe, the Colonial Surgeon, had attended him. Durie was found not guilty. ${ }^{90}$ Reporting of both inquest and trial was animated by the fact that serial requests for assistance had been sent to the hospital. None were acted upon. Secombe was responsible for the management of the hospital and of Durie. Reporting focused particularly on conflicting evidence given by Secombe. The Cornwell Chronicle was particular strident in its criticism of Secombe's role, ${ }^{91}$ who denied any wrongdoing and maintained that it was not his duty to attend to the prison, but to simply organise that care be provided to it. This was not the first time that The Chronicle had focused upon Secombe. Earlier the same year, it had published an excoriating editorial under the title "liberty with danger is to be preferred to slavery with security". 92 The editorial accused Secombe of blocking a coronial inquest into the unnatural death of another prisoner, William Morton. It argued "that medical gentlemen should ever be ready to subject their professional conduct to examination", 93 while in the refusal to examine, "the public is insulted and justice is mocked". ${ }^{94}$ In summarising the finding of the trial of Durie later that year, The Chronicle focused almost completely upon the actions of Secombe. It reported that after successive notes were ignored, a guard was sent personally to Secombe to report that "a man was very dangerously ill at the tread-mill, and that a surgeon was required there immediately". 95 Citing the public nature of his office and the duties incumbent upon him, Secombe's response to this request became a campaign:

Did Dr Secombe go? No, he did not! Did he command either of his Assistants to go? It does not appear that he did! - and in his evidence on this trial, he states that it is no duty of his to attend at the tread-mill? Whose duty is it, then, we should like to know? For what is he paid by the country? We presume it to be his duty to attend wherever sickness is, and that the public has nothing whatever to do with his assistants. It is Dr Secombe who is responsible to the public, and his duty lies as much at the tread-mill, as at the Hospital, or any other public department. ${ }^{96}$

Though in a wholly different era, the role of medical administrators in both the Patel affair as well as at Chelmsford takes centre place in the discourse of criticism raised by public scrutiny of medical misadventure. ${ }^{97}$ The responsibility of medical administrators remains central to instances of misadventure even where they themselves are not subject of prosecution. The scope and process of prosecution begs the question of the characteristics of the adverse events themselves which give rise to inquest or prosecution. As will be seen, most prosecutions cluster around particular aetiologies well known to contemporary quality and safety literature.

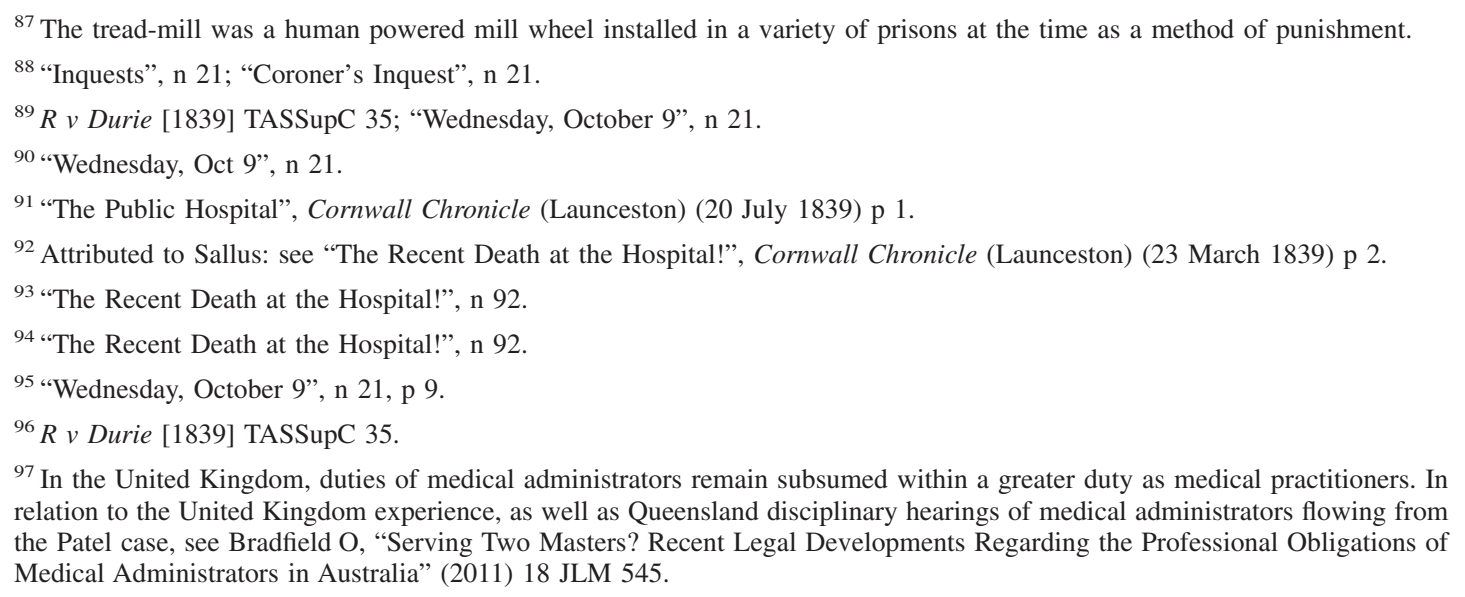




\section{Characteristics of ADVERSE EVEnTS, ERRORS AND BehaViour}

The types of adverse event or error which gives rise to a death recounted here are largely classified as related to medication error or failure in clinical process/procedure. ${ }^{98}$ There is a difficulty in assessing accurately the aetiology of iatrogenic death so far removed from its happening. As such, the classification here is not to substitute for the coroner's or court's finding, but rather as illustrative of the significant factors present in each instance of harm.

\section{Medication error}

Medication error is a significant part of contemporary iatrogenic harm. Two to $3 \%$ of all hospital admissions in Australia are medication-related and hospital incident reporting shows that incidents with medication are the second most common type reported following patient falls. ${ }^{99}$ Half of the cases described here involve medication error.

As mentioned above, the case of Dr Degner in 1861 is now the earliest known trial for medical manslaughter in New South Wales. On 11 July 1861 an inquest was held at the Dowling Street Wharf Hotel into the death of an infant, Lucy Hellings, aged six months. ${ }^{100}$ Degner was a doctor attached to a lodge of which the deceased's father was a member. The deceased was unwell, apparently suffering from a cold. Degner examined the child and made up a bottle of medicine he believed to have been potash, tartaric acid and water, but was in fact made up of potash, tartaric acid and sulphuric acid. Degner had several bottles of ingredients placed in the area where he would routinely mix prescriptions. A new surgery was being constructed at the time and some bottles had been recently moved. Amongst these bottles were two identical gin bottles, both unlabelled, one of which contained water and the other sulphuric acid. ${ }^{101}$ Degner selected the bottle containing sulphuric acid and made up the medicine. The deceased's mother administered the mixture and after a few hours the child convulsed and began to vomit. The deceased's mother reported that the "froth which issued from the child's mouth caused blisters to rise under its nose". ${ }^{102}$ After discovering the mistake, Degner threw the remainder of the medicine out of the window and sent for magnesia which he intended to use as an antidote to the acid. The child never recovered. Degner did not deny that his actions had caused the death of the child, and it was reported that on more than one occasion the coroner cautioned Degner against self-incrimination. The jury at the inquest deliberated for some time, recalling one witness to describe how the bottles of medicines were kept in the house. They returned a verdict as follows:

We the undersigned, mutually agree in opinion that the mixture administered to the child by order of Dr Degner was the immediate cause of death. At the same time we are of the opinion that Dr Degner is highly censurable in allowing the acid to be kept in a bottle resembling the one in which the water was kept, there being no label to distinguish one from the other. We exonerate Dr Degner from any wilful attempt to destroy life, but think him deserving of the severest reprimand for not exercising due caution. $^{103}$

This is not an incident of isolated medical practice in Australia. Similar incidents of medication-related iatrogenic death continue throughout the cohort of cases. This includes the cases already discussed and those to follow.

\footnotetext{
98 These classifications are drawn from the World Health Organization, International Classification for Patient Safety (2009), and are present in various forms in national or subnational adverse event classification systems.

${ }^{99}$ The Australian experience is of $2-5 \%$ drug charts exhibiting a prescribing error, and 5-18\% of medicines administered incorrectly with wrong drug, wrong patient, wrong route, wrong dose or wrong time. Intravenous medications are administered with up to $70 \%$ including an error: see Australian Commission on Safety and Quality in Healthcare, Safety and Quality Improvement Guide Standard 4: Medication Safety (October 2012) p 9.

100 "Death by Poisoning", n 76.

101 "Death by Poisoning", n 76.

102 "Death by Poisoning", n 76.

103 "Death by Poisoning", n 76.
} 
Medication errors continue to be the result at the often complex intersection of what the law might characterise as individual and systemic failure. ${ }^{104}$ In the case of Dr Gow (2004), this was not lost on Berman DCJ. His judgment made clear the tripartite balancing which the criminal law attempts in these cases. First, and principally, the need to hold front of mind that the death of a human being has taken place; secondly, that the defendant, like Gow, may be a person of indisputably "impeccable reputation and character", ${ }^{105}$ this being balanced by the need to ensure that no overshadowing of the "objective gravity of what they have done"106 is made; finally, the expressive nature of criminal law, where despite systems to prevent "a single mistake having a catastrophic consequence", ${ }^{107}$ the law must act in a manner which "will bring home to all of those involved in patient health care the seriousness which the law regards gross breaches of what is required of them". 108

Recall the case above of Dr Berthold Hiller (1941). He had negligently caused the death of a patient whom he had killed by injecting too great a dose of novocaine and adrenalin during an operation he had performed. Hiller stated in an affidavit that he was unaware before the death of the patient that the solution contained too large a quantity of adrenalin. ${ }^{109}$ Hiller performed 500 or 800 operations each year of which 150 would "be on the nose". ${ }^{110}$ He stated: "I have never, at any time, in my practice, authorised or prescribed a prescription of novocaine and adrenalin containing more than 15 minims of adrenalin to the ounce."111 Evidence received by employees of the chemist who had dispensed the solution on orders made by Hillier was to the effect that a written prescription had been received "some time after" 112 a visit by detectives to their pharmacy in relation to the death. ${ }^{113}$ One employee gave evidence that the written prescription differed from that recorded over the telephone from Hillier. The dishonesty of Hillier in this case is not present in other cases where verbal orders for medication were made. ${ }^{114}$ Despite a lack of dishonesty, medication error involving oversight by a dispensory is present in other cases.

Walter Henry Cornell (a chemist) and Dr Leonard Cyril Lade (1915) were subject to inquest and trial for manslaughter in Ballarat, in relation to the death of Elizabeth Brown of Waubra on 25 August 1915. ${ }^{115}$ The inquest found that both the "chemist and the doctor had blundered in an extraordinary way in not taking proper precautions in handling a deadly drug which had caused the death of Mrs Brown and at present he could not find any excuse for them". ${ }^{116}$ The deceased had died from ingesting strychnine which was 50 times the strength ordered. ${ }^{117}$ The Crown alleged that Cornell was grossly negligent in dispensing the prescription and Lade was grossly negligent in that he left a verbal

${ }^{104}$ That the medical literature may characterise these as systemic in nature, cause or solution is beside the point for our purposes The criminal law attempts to undertake a different set of investigations than the scientific characterisation of the cause of error - rather it attempts to describe and apportion blame using different mechanisms and understandings of shared terminology like that of "cause".

${ }^{105} R v$ Gow [2006] NSWDC 78 at [25]

${ }^{106} R v$ Gow [2006] NSWDC 78 at [25]

${ }^{107} R v$ Gow [2006] NSWDC 78 at [26].

${ }^{108} R v$ Gow [2006] NSWDC 78 at [27].

109 "Doctor on Manslaughter Case", Townsville Daily Bulletin (Townsville) (30 August 1941) p 8. The solution contained in excess of 15 minims of adrenalin.

110 "Doctor on Manslaughter Case", n 109.

111 "Doctor on Manslaughter Case", n 109.

112 "Doctor on Trial. Error Alleged in Injection used at Operation", The Mercury (Hobart) (27 August 1941) p 6; "Prescriptions by Phone. Letter did not Agree", n 81.

${ }^{113}$ The prescription had been accidently disposed of.

${ }^{114}$ Such as that of Dr Leonard Cyril Lade (1915) and Walter Henry Cornell (Chemist) (1915).

115 "Manslaughter Charge Against Doctor", n 82.

116 "Verdict of Manslaughter. Doctor and Chemist Committed for Trial. Ballarat, Friday", The Ararat Advertiser (Ararat) (28 August 1915) p 2.

117 "Verdict of Manslaughter. Doctor and Chemist Committed for Trial. Ballarat, Friday", n 116; "Charge of Manslaughter. Making up a Prescription", Northern Star (Lismore) (7 October 1915) p 4. 
order instead of a written prescription. ${ }^{118}$ The Crown adduced evidence as to Lade's misgivings about the ingredients of the medicine supplied to him when he observed that it was contained in a green bottle worded "poison" with the words "not to be taken" blown into the glass of the bottle. Lade had scratched off the direction "not to be taken" and then handed it to the patient. ${ }^{119}$ The detail of argument is lacking, whilst it is known that the judge directed the jury to return a verdict of not guilty which was done. Both Lade and Cornell were acquitted. ${ }^{120}$

Similarly, in 2004, Dr Gow had mistakenly prescribed five ampules of morphine tartrate to his patient instead of the less potent morphine sulphate. ${ }^{121}$ The patient, who was to administer this substance to himself as part of a pain management regime for chronic back pain, died after injecting himself with 120 milligrams of the substance. Gow admitted that he had failed to prescribe the correct substance and had not provided the patient with dosage instructions. He pleaded guilty to manslaughter and was given a suspended sentence. Gow was described by the trial judge as deeply remorseful for what he had done. In suspending his sentence Berman DCJ noted the failure of systems designed to stop such a "catastrophic" medical error, including review by the dispensing pharmacist. This was "not to excuse Dr Gow's errors ... but ... to recognise that people, even professional people make mistakes". ${ }^{122}$

Earlier parts of this history include a range of persons who dispensed medicines or herbal remedies in an era of unregulated pharmacy practice. ${ }^{123}$ One significant figure was Mr HE Kugelman (1908), a herbalist. He travelled extensively throughout the Commonwealth, ${ }^{124}$ his travels documented in advertisements placed in Adelaide, Melbourne, Sydney and many centres inbetween. ${ }^{125} \mathrm{He}$ launched a relatively high-profile libel action in 1899-1900 against newspaper proprietor John Norton, ${ }^{126}$ which resulted in a hung jury and no verdict. ${ }^{127}$ Later, he was charged, tried and acquitted for the manslaughter of farmer Harry Ratten of Mount Templeton in $1908 .{ }^{128}$ Kugelmann had dispensed a medicine for the victim's daughter a year prior. The victim had taken that medicine without the authorisation of Kugelmann and died. ${ }^{129}$ One newspaper wrote that the injustice of

118 "Doctor and Chemist on Trial Both Get Off. Melbourne, Oct 5", Kalgoorlie Western Argus (Kalgoorlie) (12 October 1915) p 8. In addition, Lade did not satisfy himself that the order was correctly taken down.

119 "Doctor and Chemist on Trial Both Get Off. Melbourne, Oct 5", n 118.

120 "Alleged, Manslaughter. Doctor and Chemist Acquitted. Melbourne, Wednesday", The Barrier Miner (Broken Hill) (6 October 1915) p 2; "Doctor Acquitted of Manslaughter", North Western Advocate and the Eти Bay Times (Tasmania) (7 October 1915) p 3.

${ }^{121} R v$ Gow [2006] NSWDC 78.

${ }^{122} R$ v Gow [2006] NSWDC 78 at [26].

${ }^{123}$ Including Dr Charles Zimmler who is discussed below. See, for example, the case of Lubienski, who was found guilty at first instance (later quashed by the New South Wales Supreme Court) of the malicious injury to a child during the delivery of the child. The child had died during a difficult (breach) delivery at which Lubienski, practising as a doctor but not legally qualified as such, attended: $R v$ Lubienski (1893) 14 NSWLR (NSW) 55.

${ }^{124}$ Kugelmann was a successful herbalist, purchasing an estate previously owned by Dame Nelly Melba (which included an irrigation plant that was to be the source for wartime suspicion that it was being used to send signals to German submarines or to store arms and possibly housing a field gun): McQuilton J, "German Australians in Rural Society 1914-1918" (1999) 23 J Aust Stud 178.

125 "Kugelmann", The Sunday Times (Perth) (20 September 1908) p 8; "Mr Kugelmann", The Albury Banner and Wodonga Express (Albury and Wodonga) (5 March 1915) p 45.

126 “Kugelmann v Norton", The Advertiser (Adelaide) (15 December 1899) p 5.

127 “Kugelmann v Norton”, The Goulburn Evening Penny Post (Goulburn) (10 March 1900) p 2. Kugelmann was later prosecuted under Queensland medical regulation for failing to comply with requirements to state his full name on materials published by him notifying the treatment of disease.

128 "Kugelmann Acquitted”, The Evening News (Sydney) (3 December 1908) p 5.

129 “The Kugelmann Prosecution”, The Newsletter (Sydney) (21 November 1908) p 9. 
prosecution was comparable to that of the prosecution of Pasteur, ${ }^{130}$ a reputation no doubt aided by Kugelmann's own advertising ascribing a skill of healing "unsurpassed in modern history". ${ }^{131}$

While many of the medication errors prosecuted in this history took place in the community setting, so too have hospital-based errors given rise to charges. Perth surgeon, Dr Alan Gray (1946), was committed to trial after Coroner FEA Bateman found that Gray had been negligent in his treatment of a patient, leading to her death. His case is an example of the intimate relationship between medication error, systems failure and of breakdown in clinical procedures and processes and one which is explored next. ${ }^{132}$

\section{Clinical process/procedure and the clinical team}

Ann Elizabeth Aitken, of Bedford Street, Cannington ${ }^{133}$ died on 16 May 1946 whilst at Perth Hospital undergoing a tonsillectomy. ${ }^{134}$ The cause of her death was medication error - the injections of pantocaine instead of procaine - which caused cardiorespiratory failure. Gray, her surgeon, was committed for trial for manslaughter noting that "it is the duty of the medication practitioner to use proper skills and caution in the treatment of all patients". ${ }^{135}$ Gray was tried in the Supreme Court before Sawyer CJ and found not guilty of manslaughter. ${ }^{136}$ It was reported that the surgeon almost fainted when he was informed of the verdict.

The interaction between surgeon, clinical team, process and procedure is more complex than at first glance, reconstructed here from both trial and inquest evidence.

Roma Alice Cooper, Sister-in-Charge of the outpatients' theatre in which the victim was to have her tonsillectomy stated in evidence that "on the table I placed a spray containing 2 per cent pantocaine, also a bottle of pentocaine 2 percent and a bottle of adrenalin". ${ }^{137}$ Cooper was told to prepare the patient and "sprayed her throat with pantocaine 3 times". ${ }^{138}$ Gray asked how many times the throat had been sprayed and requested that the nurse spray once more. Cooper left and when she returned, Gray was injecting the patient's throat. The patient began to cough and became very distressed. Cooper said, "I went over to the dental chair and stood near Dr Gray. He said to me: 'Is pantocaine the stuff used for tonsils?' I said, 'Yes, isn't it?' He replied, 'No, God, it's not!'"139 Gray told her to "shut up" and lifted the distressed patient from the dental chair to the operating table and began resuscitation efforts which were unsuccessful. Another doctor upon entering the theatre asked "what the blazes is this all about?" to which Gray responded "Pantocaine". The doctor responded "What, from spraying?", "No", said Gray, "injection!" 140

The complexity of the events includes evidence that pantocaine was used extensively, however, never as an injection, with reference made to a standing order which required skin testing. This rule

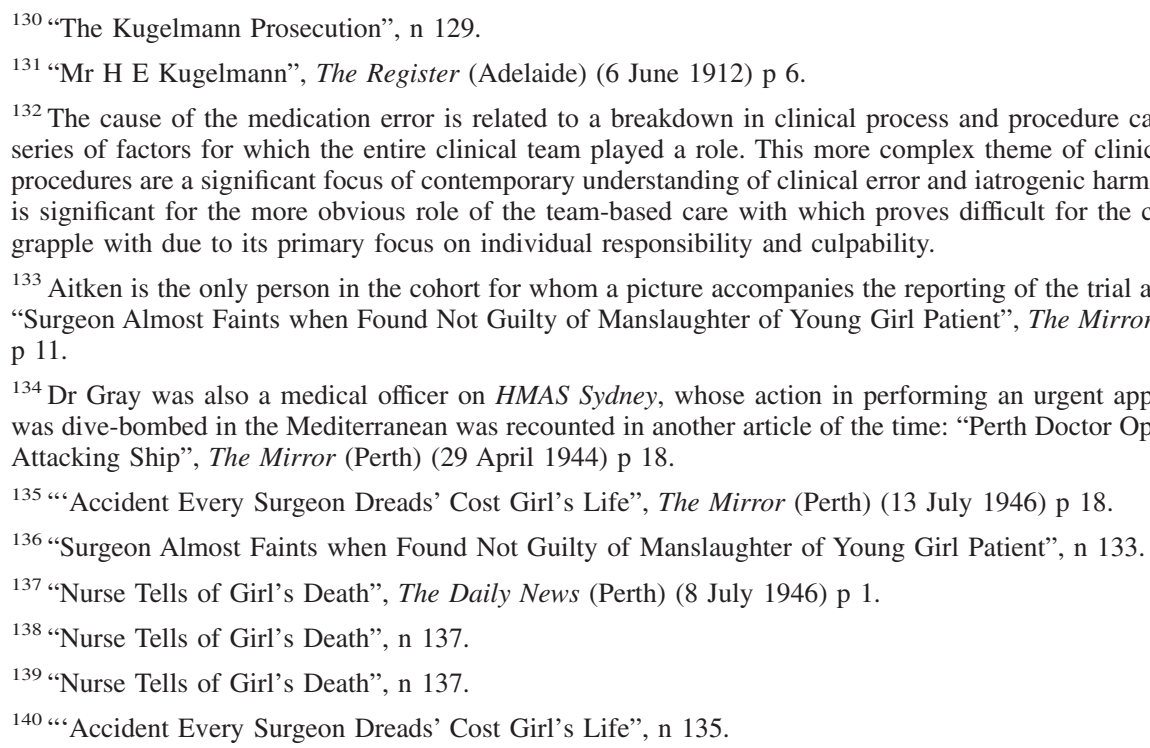
grapple with due to its primary focus on individual responsibility and culpability. p 11. Attacking Ship", The Mirror (Perth) (29 April 1944) p 18.

135 ““Accident Every Surgeon Dreads' Cost Girl's Life”, The Mirror (Perth) (13 July 1946) p 18.

136 "Surgeon Almost Faints when Found Not Guilty of Manslaughter of Young Girl Patient”, n 133.

137 “Nurse Tells of Girl's Death”, The Daily News (Perth) (8 July 1946) p 1.

138 “Nurse Tells of Girl's Death", n 137.

139 "Nurse Tells of Girl's Death", n 137.

140 “'Accident Every Surgeon Dreads' Cost Girl’s Life”, n 135. series of factors for which the entire clinical team played a role. This more complex theme of clinical systems, processes and procedures are a significant focus of contemporary understanding of clinical error and iatrogenic harm and death. Dr Gray's case is significant for the more obvious role of the team-based care with which proves difficult for the criminal law to adequately

${ }^{133}$ Aitken is the only person in the cohort for whom a picture accompanies the reporting of the trial associated with their death: "Surgeon Almost Faints when Found Not Guilty of Manslaughter of Young Girl Patient", The Mirror (Perth) (17 August 1946)

${ }^{134}$ Dr Gray was also a medical officer on HMAS Sydney, whose action in performing an urgent appendectomy whilst Sydney was dive-bombed in the Mediterranean was recounted in another article of the time: "Perth Doctor Operates with Dive-Bombers 
was not strictly adhered to in the hospital and "in this case, the amount of pantocaine injected would have been fatal to anyone". ${ }^{141}$ Similarly, different drugs were coloured, with procaine left uncoloured so as to avoid confusion between them. Whilst theatre records (contained in a little black book) recorded the setup regularly used by Gray which included pantocaine. ${ }^{142}$ This case, alongside that of Gow, draws attention to the intersection between system failure as well as error on the part of individual practitioners which is at the heart of debates about the criminal law's role in iatrogenic harm.

Seven years before Gray's case, another female patient died after a tonsillectomy: Lottie Marion Meek, 51, died on 26 May 1939. ${ }^{143}$ An inquest was held into the death with post-mortem evidence submitted which showed that the death was due to a trachea obstruction by a gauze "wad" (or swab) which had remained in-situ until post-mortem examination. ${ }^{144}$ This had caused asphyxia. In this instance, Dr Adrian Ward-Farmer, an ear, nose and throat specialist, had performed the operation. ${ }^{145}$ In evidence, Nurse Eileen Veronica Kelly stated that she had not kept a check on the dabs (swabs) used in the operation and added that it was the surgeon's responsibility to do so, testimony which the anaesthetist also gave. The Coroner, Mr TH Hannah SM, noted that both Ward-Farmer and the anaesthetist, Dr Stanton "did everything possible in the circumstances for this unfortunate woman", ${ }^{146}$ finding that the patient died from what was described as sheer misadventure. A coronial recommendation that someone should be appointed to check swabs or dabs used in the operation are accounted for was made which was targeted directly at the system error at the root of this "misadventure". 147

While it is easier to understand the various errors at the centre of each of these mid-20th century cases, other older cases seem unreadable within contemporary expectations and practices of medicine. The case of Dr Loughnan (1911) is illustrative. A coronial inquest was held at the Daylesford Hospital in Victoria into the circumstances surrounding the sudden death of Elizabeth Ann Bell on 20 November $1911 .{ }^{148}$ The coroner found that the death was due to heart failure "induced by influenza, hard work and worry". ${ }^{149}$ Whilst the diagnosis seems aged, the case remains relevant in relation to medical culture. Loughnan had been called to consult on the patient either at a late hour or in other circumstances wherein he claimed that it was medical etiquette not to consult on her. Commenting on Loughnan's refusal to attend the patient when called, the coroner said that "if that was medical etiquette, the sooner it was amended the better", ${ }^{150}$ noting that he was not placing blame for the death on Loughnan, but that in cases of life and death it would be better if medical etiquette were set aside. Whether Loughnan's case is best understood as sheer callous disregard for the life of a patient or his duty is unclear.

\footnotetext{
141 ““Accident Every Surgeon Dreads' Cost Girl's Life”, n 135.
}

142 The scenario described in the case of Gray has some resonance with the case of Prentice and Sullman in the United Kingdom: $R v$ Prentice [1993] 4 All ER 935.

143 "Died Two Hours after Tonsils were Removed. Swab in Perth Woman's Throat. Doctors Describe Operation", The Mirror (Perth) (15 July 1939) p 15.

144 "Woman's Death after Operation. Evidence that Gauze Swab was Found in Windpipe. Perth, July 13", The Morning Bulletin (Rockhampton) (14 July 1939) p 9.

${ }^{145}$ Dr Alan Gray (1946) had provided treatment to the patient post-operatively whilst recovering on the ward. It was Gray who was to contact Dr Ward-Farmer to inform him that his patient had died: "Died Two Hours after Tonsils were Removed. Swab in Perth Woman's Throat. Doctors Describe Operation", n 143

146 "Swab Case 'Death Due to Misadventure"”, The Sunday Times (Perth) (23 July 1939) p 3.

${ }^{147}$ This case is the first in the cohort where it was reported that a coronial recommendation was made to improve processes and to prevent the repeat of an event. The Coroner noted that it should not be the surgeon who is responsible for these swabs.

148 “'Medical etiquette.' Strong Remarks by Coroner”, The Barrier Miner (Broken Hill) (29 November 1911) p 2.

149 “'Medical etiquette.' Strong Remarks by Coroner”, n 148.

150 “"'Medical etiquette.' Strong Remarks by Coroner”, n 148. 
Loughnan, in a strange turn of events, was to become the victim himself to death at the hands of a doctor some 25 years later. In 1936, Dr Bothamley entered a police station and announced that "I have killed Dr Loughnan in my surgery". ${ }^{151}$ At the surgery, Bothamley said to police:

we had a few words about an agreement. I was giving him a post-dated cheque when he called me a ----, and grabbed me by the throat. He nearly choked me. When we got up, Loughnan rushed at me. I hit him two or three times with a tyre lever. ${ }^{152}$

Bothamley produced the agreement for the purchase of the practice where Bothamley agreed to pay Loughnan 1,000 pounds by 3 May 1935 and 1,125 pounds in four half-yearly instalments. ${ }^{153}$ Bothamley told Loughnan that he might delay for three months writing out a post-dated cheque to 1 January $1936 .{ }^{154}$ He claimed self-defence from the choking attack. He was found not guilty of manslaughter. ${ }^{155}$

Failure to attend is a rarity in the cohort, as are female defendants. Apart from Dr Pearce (2000) (discussed earlier), the only other female defendant appears to be Dr Lebanon (1946), a medical practitioner charged with manslaughter by criminal negligence. This case is discussed below as are other gender-related themes. The most striking gender-related theme is the almost universal existence of a female victim at the centre of all but three of the principal cases rediscovered by this study. ${ }^{156}$

\section{CharActeristics OF VICTIMS AND DEFEnDANTS}

\section{Women as defendants}

Lebanon was deputising for Dr Alexander Ryan at the confinement and delivery of Mrs Dorothy Peters, 28, of Bondi, at War Memorial Hospital on 24 March 1946. The patient died and an inquest was called. The husband of the deceased accused both Lebanon and Ryan of negligence, arguing that he had engaged Ryan because of "the reputation of American experience". 157 Lebanon was "a substitute in the person of a young and apparently inexperienced woman, who could not tell the difference between heart collapse and asphyxia". ${ }^{158}$

During her delivery, the deceased had ceased breathing. Lebanon instituted artificial respiration after excluding either anaesthetic or obstetric shock. She had attempted to locate any foreign bodies in the deceased's throat. After the resuscitation efforts had failed, Lebanon noticed small solid pieces of substance in a brown stain on the sheets near the deceased's head. They looked to her "like chicken or veal". ${ }^{159}$ Nurses noted that this could not be possible. Lebanon referred the death to the coroner for post-mortem examination and queried the midwife in charge of the labour ward who reported the patient had only ingested light milk food prior to her confinement.

Findings of the post-mortem examination were that the patient had died due to asphyxia, due to the inhalation of stomach contents which included green peas. It emerged during the inquest that the patient had been given a meal which consisted of chicken, peas, mashed potatoes, pumpkin, apple and

151 "Doctor's Death after Struggle in Surgery. Coroner's Finding of Manslaughter. Melbourne, Friday", The Sydney Morning Herald (Sydney) (14 December 1935) p 18.

152 “Doctor's Death after Struggle in Surgery. Coroner's Finding of Manslaughter. Melbourne, Friday”, n 151.

153 "Doctor's Death in Surgery. Manslaughter Finding by Coroner. Evidence of Fight. Melbourne. December 13", The Advertiser (Adelaide) (14 December 1935) p 20.

${ }^{154} \mathrm{He}$ denied that he had post-dated the cheque because he did not have the money, stating that he had only done so because Dr Loughnan had not kept to his agreement.

155 "Manslaughter Charge. Melbourne Doctor Acquitted. Melbourne, Friday", The Western Champion (Barcaldine) (21 March 1936) p 12.

156 This excludes male patients of Dr Patel and of Drs Bailey, Herron and Gill at the Chelmsford Private Hospital.

157 “Labour-Ward Death. Doctor's Evidence”, The Sydney Morning Herald (Sydney) (25 June 1946) p 4.

158 “Labour-Ward Death. Doctor's Evidence", n 157.

159 “Labour-Ward Death. Doctor's Evidence", n 157. 
milk jelly at $12.15 \mathrm{pm}$ with the patient taken into the labour ward at $3.00 \mathrm{pm} .{ }^{160}$ Sister Eunice Isobel Baker is reported to have said that she had given the patient the meal but "did not consider it a matter of great importance"161 that she should tell the midwife who had relieved her. ${ }^{162}$ Lebanon did not blame the hospital or the nursing staff for the death, nor did Lebanon accept "one iota" 163 of responsibility for the death. Lebanon noted that had she been made aware that the patient had in fact eaten, she would not have administered an anaesthetic.

The coroner was reported to have "sharply criticized"164 Lebanon, finding that:

Dr Lebanon, in my opinion, failed to realize the significance of the fact that the patient's condition began to deteriorate immediately after the vomiting. The colour of the patient should have been further confirmation that asphyxia was the probable cause of the patient's collapse. I find that the anaesthetic was administered by Sister Moorebank under the direction of Dr Lebanon who made no inquiry before the administering about the food [intake] by the deceased. The [failure] of Dr Lebanon in not keeping the patient under ... supervision can be attributed to her inexperience. ${ }^{165}$

A verdict of accidental death was recorded by the coroner.

In similar circumstances to the death of Peters, the death of Cecil Charles Webb, in Adelaide in 1921 gave rise to the eventually dismissed prosecution of Drs Turner, Steven and Hussey of the Adelaide Hospital. ${ }^{166}$ In short, Webb had been anaesthetised for surgery to repair a lacerated hand. The coroner found he had asphyxiated during the anaesthetic, choking on his own vomit. In a rare instance, Webb's mother acted as Prosecutrix, bringing before a very hostile court charges of manslaughter against the three. ${ }^{167}$ After initial hearings with significant complaints by the Prosecutrix's counsel, the matter was dropped. ${ }^{168}$

\section{Women as victims}

While female defendants are the subject of two cases in the cohort, women are strongly represented as victims. This includes women who died as a result of terminations of pregnancy. However, the cases included in this article are limited to those based on facts unrelated directly to termination of pregnancy. ${ }^{169}$ Cases of manslaughter by criminal negligence by virtue of a death associated with an illegal termination of pregnancy represent the most significant part of prosecution in Australia due to both the significant number of cases and the intersection between properly iatrogenic factors and a legal apparatus which criminalised the undertaking of the procedure at all. ${ }^{170}$

To provide a sense of the type of case found in this termination of pregnancy-related cohort, that of Dr Frederick William Marshall (two instances in 1904 and two in 1905) and Dr Sarsfield Cassidy (1921) stand as representative cases. ${ }^{171}$ Marshall's is one of earliest termination-related manslaughter case found in this study. He was subject to three retrials in one matter, in addition to a further three

160 “"Hazards of Life'. Woman's Death in Childbirth”, The Sydney Morning Herald (Sydney) (23 July 1946) p 4.

161 “Labour-Ward Death. Doctor's Evidence", n 157.

162 “'Hazards of Life'. Woman's Death in Childbirth”, n 160.

163 "Woman Doctor Will Not Accept Onus for Death in Childbirth", The Barrier Miner (Broken Hill) (23 July 1946$)$ p 6.

164 “Woman Doctor Criticised. Coroner's Stern Comment”, The Sydney Morning Herald (Sydney) (25 July 1946) p 4.

165 "Doctors Criticised In Childbirth Case", The Newcastle Morning Herald and Miners' Advocate (Newcastle) (25 July 1946) p 6.

166 “Charge against doctors, Negligence in Hospital alleged”, The Argus (Melbourne) (9 August 1921) p 7.

167 “Court Sensation, A Magistrate Lectured”, Western Mail (Perth) (18 August 1921) p 34.

168 "Charges against doctors, Informations dismissed”, Kalgoorlie Miner (Perth) (6 September, 1921) p 5.

${ }^{169}$ Women were the victims in 22 cases in the cohort.

${ }^{170}$ The cases relating specifically to the provision of termination services will be the subject of future publication. To date they exceed some 60 cases of "illegal operations" which resulted in the death of the patient and which were prosecuted with a manslaughter-related charge.

${ }^{171}$ In a significant number of cases, nurses and lay-women were prosecuted for manslaughter, or in some cases both the person identified as the practitioner and the patient's husband or partner. 
inquests and trials for separate allegations of manslaughter. His alleged guilt is based on the performance of what newspapers at the time referred to simply as an "illegal operation".

On 23 March 1905, Marshall was charged with the manslaughter of Amelia Lynch, 26, of Young, by performing an illegal operation on 27 August 1904 in Sydney. ${ }^{172}$ At the inquest, held in late 1904, it was reported that Lynch had died at the house of a nurse after the operation. ${ }^{173}$ At trial, Marshall entered a plea of not guilty, but the jury was unable to reach a verdict initially. Simpson $\mathrm{J}$ then addressed the jury in relation to a memorandum sent to him the previous afternoon that a number of jurors had not quite understood the question which they were asked to determine. The jury were asked to deliberate again but returned confirming that they were not able to reach consensus. ${ }^{174}$ Bail was set at 200 pounds with Marshall held on remand. The first retrial began in 1905 under Murray AJ at Central Local Court. ${ }^{175}$ The jury again was unable to reach a consensus in the trial. ${ }^{176}$ A second retrial concluded on 7 June 1905 with the acquittal of the accused. ${ }^{177}$ In a statement, Marshall said that his certificates and diplomas were of the highest character ${ }^{178}$ and that:

I risked my liberty to try to save life, and because I did so I am persecuted by three trials, and at a time when I met with serious accidence [sic] because after the last trial I got spinal meningitis, and when I returned home it was only to see my wife die. In less then four weeks from the time of her death I am ordered to present myself again for trial on a charge of which I am entirely innocent. ${ }^{179}$

Marshall had been tried on a number of occasions, each in relation to termination-related complications. ${ }^{180} \mathrm{He}$ had been tried in 1904 for the death of Euphemia Franklin, 28. ${ }^{181}$ A verdict of "wilful murder" was returned at the inquest into the death of Franklin with another, Thomas Ireland, being named as an accessory, the latter having "kept company"182 with the deceased. Both were committed to trial, the result unknown. Marshall was also charged in relation to an alleged unlawful use of an instrument to procure a miscarriage upon Ethel Ogilvie, "a married woman". ${ }^{183}$ Dr Walter AR Sharp, resident medical officer of the Coast Hospital at Little Bay, had called on Ogilvie and worked to treat her severe bleeding after Marshall had allegedly performed the procedure. Marshall was committed for trial at the Central Criminal Court on 5 April 1904 and was released on bail. Further, an inquest was held into another death related to Marshall in 1905. Martha Frances Walker, 30, had died on 17 November 1905 at the Sydney Hospital after being admitted four days before. ${ }^{184}$ The inquest was held with Marshall, Andrew Moorehead (warder at Gladesville Asylum where the deceased had been employed as a nurse) and Catherine Steppe all present. Marshall was

172 "Suspicious Circumstances. The Inquest Adjourned. [By Telegraph] Sydney, Friday", The Singleton Argus (Singleton) (3 September 1904) p 5.

173 “Suspicious Circumstances. The Inquest Adjourned. [By Telegraph] Sydney, Friday”, n 172.

174 "Central Criminal Court (Before Mr Justice Simpson and a Jury of 12) The Solicitor-General (Mr Hugh Pollock) Prosecuted for the Crown. Alleged Manslaughter. Dr F W Marshall's Trial. Jury Disagree", The Sydney Morning Herald (Sydney) (30 September 1904) p 7.

175 "Charge of Man-Slaughter. Dr F Marshall on Trial. The Death of Amelia Lynch", The Evening News (Sydney) (20 March 1905) p 4.

176 "Charge of Man-Slaughter. Dr F Marshall on Trial. The Death of Amelia Lynch”, n 175.

177 "Central Criminal Court (Before Mr Justice Simpson and a Jury of 12)", n 174.

178 "Central Criminal Court (Before Mr Justice Simpson and a Jury of 12)", n 174.

179 "Central Criminal Court (Before Mr Justice Simpson and a Jury of 12)", n 174.

${ }^{180}$ Dr Marshall had also been the subject of a civil case in 1897 brought by Lawrence McGrath, a publican, for the recovery of 500 pounds from Marshall for the use of his hotel for an "immoral purpose". It was found that Marshall had presented to the hotel with a woman whom he reported to be his wife. After it was discovered that the couple were in fact not married, he was ordered out of the hotel. The doctor had offered a defence that he was simply attending to the woman as her physician and denied the charge of undue intimacy. The jury found for the plaintiff assessing damages at 20 shillings.

181 “Dr Marshall Again [By Telegraph] Sydney, Wednesday”, The Barrier Miner (Broken Hill) (2 June 1904) p 4.

182 "Dr Marshall Again [By Telegraph] Sydney, Wednesday", n 181.

183 “In Trouble Again”, The Raleigh Sun (Bellingen) (25 March 1904) p 2.

184 "New South Wales. Another Victim. Sydney, Saturday", Morning Post (Cairns) (20 November 1905) p 3. 
committed to trial for "using an instrument on Martha Frances Walker", with Moorehead and Steppe both charged with procuring an operation. ${ }^{185}$ They were each charged with murder. ${ }^{186}$ The Crown (Mr Pollock) submitted that the evidence was insufficient to secure a conviction, instead recommending that the court not proceed with the case. ${ }^{187}$

Marshall was not the only doctor to be brought before the courts multiple times on charges related to terminations. So too was Dr Andrew Sarsfield Cassidy (1921) of Sydney. Cassidy was discharged from custody on 10 February 1922 when police stated that they had no fresh evidence to offer after the Attorney-General directed them not to proceed with prosecution. ${ }^{188}$ This charge was in connection with a death described as being at the Coast Hospital, and also at a private hospital in Darlinghurst, ${ }^{189}$ of Isabel Dargaville, a young nurse, on 12 December $1921 .^{190}$ The coroner found that the cause of death was septic pericarditis "following a certain event, which he was unable to say how or by whom that event was brought about". ${ }^{191}$ The media reported that following the inquest, Cassidy was brought before the Central Police Court on a charge of feloniously and maliciously slaying Dargaville, in which the magistrate was reported to have remarked that "he had no doubt that the Attorney-General would take a certain course of action if no fresh evidence is forthcoming". ${ }^{192}$ Cassidy and Dr Albert Reginald McLeod were key persons of interest in another coronial inquest held earlier in 1921 in relation to the death of Gwendoline Campbell Glass, 20, at the Coast Hospital on 27 November 1920. ${ }^{193}$ Cassidy was committed to trial for murder by the coroner, McLeod was discharged. ${ }^{194}$ Reports state that Cassidy was acquitted of murder relating to this death in March 1922. ${ }^{195}$

These termination of pregnancy cases exhibit a shared texture due to the way in which newspapers reported such cases; the use of euphemism and a blurring of the facts of the cases characterised the tone of the reporting. This seems also to be the character of the cases at trial, with cases often presenting conflicting evidence and unclear timelines. Many of the cases involve multiple retrials, successive acquittals and registered physicians, midwives, nurses and untrained persons subject to prosecution. ${ }^{196}$

\section{Recidivism}

The visibility of untrained or otherwise unregistered practitioners is pronounced too in a select group of early recidivist cases unrelated to terminations of pregnancy. One of the earliest cases in the cohort speaks to the question of repeat offending, prosecution and untrained practitioners. The case of

\footnotetext{
${ }^{185}$ Although the reports of the time also refer to the charge being that of murder.

186 "Charge of Murder", Clarence Richmond Examiner (Grafton) (9 December 1905) p 4; "New South Wales. Break-Down of a Murder Trial. Sydney, March 27”, The Mercury (Hobart) (28 March 1906) p 3.

187 “Dr Marshall Acquitted Dying Depostions Rejected. Sydney, March 27”, The Advertiser (Adelaide) (28 March 1906$)$ p 8.

188 "Death of a Girl. Dr Cassidy Discharged", The Argus (Melbourne) (10 February 1922) p 12.

${ }^{189}$ The Coast Hospital of the time was largely an infectious diseases and quarantine hospital, later renamed Prince Henry Hospital, in Little Bay. Reports conflict as to the location and/or name of the hospital in question, naming the Coast Hospital as a private hospital in Darlinghurst.

${ }^{190}$ Isabel Dargaville is also various referred to as Isabel d'Argaville, "Nurse's Death. An Open Verdict", The Sydney Morning Herald (Sydney) (7 January 1922) p 14.

191 "Death of Isabel Dargaville. Sydney Doctor Remanded on Manslaughter Charge. Sydney, Friday", The Barrier Miner (Broken Hill) (6 January 1922) p 1.

192 "Death of Isabel Dargaville. Sydney Doctor Remanded on Manslaughter Charge. Sydney, Friday", n 191.

193 "No Title", Queanbeyan Age and the Queanbeyan Observer (Queanbeyan) (29 November 1921) p 3; "Alleged Malpractice Charge Against Two City Doctors (By Telegraph) Sydney, Monday", The Singleton Argus (Singleton) (13 December 1921$)$ p 2.

194 “Young Woman's Death. A Doctor Committed. Sydney, Dec 12”, The Western Australian (Perth) (13 December 1921$)$ p 7.

195 "Doctor Acquitted. Sequel to Young Woman's Death. Sydney, March 23", The Register (Adelaide) (24 March 1922) p 9. There are conflicting media reports which state that this earlier of the two charges was in fact dropped due to the more serious charge of murder being laid in relation to the later death of Dargaville.

${ }^{196}$ This material is the subject of a forthcoming publication.
} 
"Professor" Davies and Dr Spark (1897) ${ }^{197}$ gives an insight into a range of challenges for the regulation and practice of medicine at the time. Davies and Spark were charged and tried for the manslaughter of Margaret Steel whom they had treated for cancer of the breast. ${ }^{198}$ Spark was a qualified physician whilst "Professor" Davis, was not qualified, but was a man who held himself out to be a cancer specialist.

At the inquest, the husband of the deceased described Davis' treatment, alleging that he had applied a plaster and said it would not give pain, but that the cancer would come away in a lump from the body. A report regarding both a piece of cloth smeared with ointment and also a piece of flesh which had been taken for analysis showed the ointment to have been a strong arsenical preparation. ${ }^{199}$ Evidence showed that the treatment had in fact caused significant pain. ${ }^{20}$ Post-mortem evidence showed that there was a cancerous growth on the left breast, the skin having been completely eaten through by a strong corrosive. The immediate cause of death was stated as a "flabby heart and engorged lungs". ${ }^{201}$ In evidence, the physician who undertook the post-mortem examination noted that arsenic would have been absorbed into the body from the ointment used by Spark and Davies and that the deceased may have died from poisoning which would account for the ulceration. ${ }^{202}$ Spark gave evidence to the inquest and denied that the preparation used on the plaster contained arsenic. ${ }^{203} \mathrm{He}$ noted that Davis had been acting under his instruction, Spark being a qualified medical practitioner. Coroner Davis had regard to a previous sentence of imprisonment for the manslaughter of a "certain woman in the past". ${ }^{204}$ The coronial jury found that the deceased had died from improper treatment by Spark and Davis, and that both were guilty of manslaughter. Both were committed to trial.

The trial was concluded on 30 June 1897 with Horten J deciding to admit evidence of alleged cures of cancer previously effected by Davies. ${ }^{205}$ It was reported in the press that the judge summed up strongly in favour of the accused and the jury returned a verdict of not guilty.

Spark and Davis were again committed to trial for manslaughter shortly after for the death of another patient, Margaret Beamish. ${ }^{206}$ Whilst treating her for cancer of the tongue, reports stated that plasters containing arsenic were again used by Spark and Davis in the treatment of Beamish. ${ }^{207}$ The deceased developed septic pneumonia, and was reported to have resulted from the "treatment". ${ }^{208}$ The inquest found both guilty of manslaughter and both were again committed to trial for murder. The case ended with the prosecution entering a nolle prosequi in connection with the preferred charge of murder made against Davis and Spark. ${ }^{209}$

${ }^{197}$ The Australian Medical Pioneers Index provides a detailed listing of Dr Spark's postings and life in Australia: see the entry for "Sidney Walter Spark" (last updated 31 January 2012), http://www.medicalpioneers.com/cgi-bin/index.cgi? detail $=1 \& i d=2080$.

198 "Charged with Manslaughter. Committed for Trial. Melbourne, Thursday", Launceston Examanier (Launceston) (23 April 1897) p 6; "Latest Telegrams. Melbourne, Thursday Night", The Horsham Times (Horsham) (23 April 1897) p 2; "Unregistered Medicoes in Trouble. Committed for Manslaughter. [By Telegraph] Melbourne, Thursday Afternoon", The Barrier Miner (Broken Hill) (23 April 1897) p 1; "Colonial. Medical Manslaughter. Melbourne, Friday", The Mildura Cultivator (Mildura) (24 April 1897) p 5.

199 “Latest Telegrams. Melbourne, Thursday Night”, n 198.

200 "Latest Telegrams. Melbourne, Thursday Night", n 198.

201 "Latest Telegrams. Melbourne, Thursday Night", n 198.

202 "Latest Telegrams. Melbourne, Thursday Night", n 198.

203 "Latest Telegrams. Melbourne, Thursday Night", n 198.

204 "Latest Telegrams. Melbourne, Thursday Night", n 198.

205 “Trial for Manslaughter. The Accused Acquitted. Melbourne, June 30”, The Advertiser (Adelaide) (1 July 1897 ) p 5.

206 “A Suspicious Death. Melbourne, Monday Night”, The Horsham Times (Horsham) (24 August 1897) p 3; “A Charge of Manslaughter. Melbourne, August 27”, The Advertiser (Adelaide) (28 August 1897) p 7.

207 "Victoria. Alleged Manslaughter. Melbourne, August 27", The Daily News (Perth) (28 August 1897) p 3.

208 "Victoria. Alleged Manslaughter. Melbourne, August 27", n 207.

209 “Latest Intelligence. A Nolle Prosequi. Melbourne, Thursday Night”, The Horsham Times (Horsham) (1 October 1897) p 3. 
Another fascinating case is that of Dr Cecil Rutherford Darling (1950). Darling was posted to Sofala General Hospital. Approximately 80 years of age, he had been interviewed by New South Wales police for falsely representing himself as a medical practitioner and other alleged offences. ${ }^{210}$ After being interviewed and released to collect his credentials, Darling went missing. The same man was convicted for manslaughter when acting as locum tenens at Stoke-on-Trent Maternity Hospital in Britain a decade earlier. ${ }^{211}$ At that time, it was revealed that he was not in fact a qualified medical practitioner and was described by British police as a "callous, unscrupulous, persistent rogue".212 Sentenced to 10 years gaol for manslaughter, ${ }^{213}$ his real name was reported to have been Andrew John Gibson, and he had admitted to posing as "Harry Cecil Rutherford Darling", a medical practitioner from Australia. He had done so since 1923, changing his name by deed poll. ${ }^{214}$ In remarks at sentence, Hallett J (at the Stafford Assizes), commented that he "had capped a long and extremely wicked career with about the worst case of manslaughter by negligence I can imagine. I am going to do my best to see that you kill no one else."215

"Darling" had then travelled to Australia, posing again as a doctor using the same adopted name he had since 1923. Australian police stated that "Darling" had numerous previous convictions, including where he had posed as a Presbyterian minister having had "had a great influence over women". ${ }^{216}$ Police had compiled a detailed record of his activities over a period of 57 years which included approximately 40 pseudonyms, a bride in Sydney whom he had deserted for a second bride in Brisbane, ${ }^{217}$ whom he had taken to America and had then abandoned in Canada. ${ }^{218}$ Described as $^{2}$ one of the "most daring imposters, bogus doctors, and deceivers of women in the history of crime",219 he had spent more than 40 years in gaols in America, England and Australia. ${ }^{220}$ In relation to his arrest in 1950, police would not reveal the charge contained in the warrant for his arrest, stating that they did not want Darling to know what he would be charged with until he was arrested. ${ }^{221}$

Darling is clearly an outlier in the cohort. However, in an earlier case involving Dr Charles Zimmler (1871), a similarly diverse career path was evident. Zimmler's pharmacy in Gulgong in the central tablelands of New South Wales was the subject of a photograph by the American \& Australasian Photographic Company in $1870 .^{222}$ It is reported that Mr Henry Kirke White is pictured in the photograph. White provided locum services at the pharmacy whilst Zimmler was serving six months' imprisonment for the manslaughter of a child. Reported to have been a medical practitioner from Germany, Zimmler was not registered to practise in New South Wales. Instead, he operated a

210 “'Doctor' World Impostor?”, The Courier-Mail (Brisbane) (26 May 1950) p 1; "Man Posed as Doctor for Six Weeks”, The Argus (Melbourne) (29 May 1950) p 3.

211 "Bogus Doctor Kills Woman. London, Thursday", The Daily News (Perth) (12 July 1940) p 3.

212 "Bogus Doctor Kills Woman. London, Thursday", n 211.

213 "Bogus Doctor Kills Woman. London, Thursday”, n 211.

${ }^{214}$ The judge in the United Kingdom had questioned Gibson as to why he chose the specific name, revealing that he had done so in order to be mistaken for another highly qualified doctor of the same name. The real Dr Darling practised at Macquarie Street in Sydney and had no connection with Gibson.

215 "Bogus Doctor Kills Woman. London, Thursday", n 211.

216 "Bogus Doctor Kills Woman. London, Thursday", n 211

217 "Had About 40 Aliases. Sofala's Bogus Medico", Townsville Daily Bulletin (Townsville) (27 May 1950) p 5.

218 This woman subsequently approached a Brisbane newspaper to recount the story of her abandonment, “'He was Brilliant'. Married 'Bogus Doctor"', The Courier-Mail (Brisbane) (29 May 1950) p 1.

219 "Women Swear by Bogus Doctor of 80", The Sunday Mail (Brisbane) (28 May 1950) p 3.

${ }^{220}$ This may have included a finding of guilt for forgery in South Africa, and in 1938 another forgery charge under his own name in Sydney, Australia: "Had About 40 Aliases. Sofala's Bogus Medico", n 217; "Expert Forger, Sent to Gaol for Life. Johannesburg, October 19", The Advertiser (Adelaide) (20 October 1916) p 9; "Doctor of Medicine Remanded. Charge of Forgery. Sydney. Tuesday", Muswellbrook Chronicle (Muswellbrook) (25 January 1938) p 2.

221 "Man Posed as Doctor for Six Weeks", n 210.

${ }^{222}$ American \& Australasian Photographic Company, Gulgong Dispensary Chemist \& Druggist Dr Zimmler (State Library of New South Wales, 1870). 
pharmacy, from which he had dispensed ammonia for the treatment of the child, Mary Redmond, aged 11 months. ${ }^{223}$ Zimmler was to be brought before the court for the death, having "killed and slain" her on 14 June $1871 .{ }^{224} \mathrm{He}$ was found guilty the following year. ${ }^{225} \mathrm{He}$ returned to practise as a pharmacist in Gulgong, being subsequently elected four times as mayor. His terms in office were reported to have been "very stormy". ${ }^{26}$ Other sources extend Zimmler's criminal and political history. Zimmler was again subject to an inquest ${ }^{227}$ for the death of John Millard. Evidence was given that Millard had died of a strangulated hernia, and that Zimmler's diagnosis was incorrect and treatment accelerated Millard's death. ${ }^{228}$ It seems that no charges were laid for his part in the death. In 1873, Zimmler was again a witness in an inquest, this time into the death of Patrick Shannon, a butcher. Zimmler had dispensed six grains of strychnine to the deceased, ${ }^{229}$ reporting that he had known the deceased for some time, had initially refused to sell the poison, however, had done so after he reported it was for his employer to destroy cats. The deceased had signed Zimmler's receipt book on behalf of his employer.

A decade after serving his sentence for manslaughter of the unnamed child, Zimmler was appointed a Magistrate by the New South Wales government. ${ }^{230}$ The appointment was met with some debate in the Legislative Assembly between Henry Parkes and others a year after his appointment. It was reported to have centred on Zimmler's character and fitness for the position. ${ }^{231}$

\section{CONCLUSION}

This account of prima facie cases of manslaughter in the medical context generated in the jurisdiction is significant. From five known prosecutions of doctors and one of a dentist, there is now access to an expanded case history of 33 previously little known narratives of iatrogenic death that engaged coronial and judicial processes. This increased access to case law places the matter of Patel in a far more detailed context and within an historical arc of cases otherwise forgotten by the limited horizons the current literature provides. So too does it provide at least some contextualisation to other failures to render health care free of the preventable adverse events which are associated with some $10 \%$ of all admissions to acute care hospitals ${ }^{232}$ and for which death is the most extreme outcome. This research is part of a larger undertaking which sees the criminal law's engagement as a resource of significant strength for the difficult project of improvement and innovation in health care, whilst allowing us to speak in a richer, more morally engaged public discourse about the contested question of the care of strangers.

\footnotetext{
223 "Incautious Use of Ammonia", The Sydney Morning Herald (Sydney) (20 June 1871) p 4; "A Chemist Committed for Manslaughter", Newcastle Chronicle (Newcastle) (22 June 1871) p 4.

224 “Chronicle of Events, 1871. January”, The Sydney Morning Herald (Sydney) (30 December 1871) p 5.

225 "The Circuit Courts. Bathurst”, Australian Town and Country Journal (Sydney) (27 April 1872) p 5; "The Committal of Mr Zimmler for Manslaughter”, Maitland Mercury and Hunter River General Advertiser (Maitland) (22 June 1871$)$ p 4.

${ }^{226}$ From the description accompanying American \& Australasian Photographic Company, n 222.

${ }^{227}$ Held on 21 December 1871.

228 "General News", Maitland Mercury and Hunter River General Advertiser (Maitland) (21 December 1871) p 3; "Chronicle of Events, 1871. January”, n 224.

229 "Gulgong. August 7", Australian Town and Country Journal (Sydney) (16 August 1873) p 7.

230 “New Magistrates", The Sydney Morning Herald (Sydney) (6 October 1882) p 5.

${ }^{231}$ Copies of all documents relating to his appointment were requested by at least one member of the House: "New South Wales. [From Our Own Correspondents] Sydney, February 6", The South Australian Advertiser (Adelaide) (7 February 1883) p 5.

${ }^{232}$ Corbett A, "Regulating Compensation for Injuries Associated with Medical Error" (2006) 28 Syd L Rev 259 at 259; Corbett A, Travaglia J and Braithwaite J, "The Role of Individual Diligence in Improving Safety" (2011) 25 J Health Organ Manag 247 at 248, http://epress.lib.uts.edu.au/research/handle/10453/19018.
} 